\title{
RODINA VERZUS PRÁCA: PRENOS, POZITÍVA, ZMENY
}

\author{
Jakub Pikna \\ Katedra sociálnej práce a sociálnych vied FSVaZ UKF Nitra \\ jakub.pikna@ukf.sk
}

\begin{abstract}
Abstrakt: Článok pertraktuje vzt’ah medzi pracovnými povinnost’ami a rodinným životom v kontexte prelínania oboch oblastí, pozitív a zmien. Hlavným ciel'om výskumu je identifikovat' problémové oblasti vychádzajúce z konfliktu medzi prácou a rodinou. Výskumný súbor tvorilo 130 respondentov, z nich bolo 82 žien a 48 mužov. Výskumnou metódou bol neštandardizovaný dotazník vlastnej produkcie. Dáta boli spracované jednoduchou analýzou početností a percentuálnym vyjadrením.Najväčšou bariérou vzt'ahu práce a rodinného života je absencia hraníc medzi oboma skúmanými oblast'ami. Až 68\% respondentov pracuje z domu, v rámci mimopracovného času. Medzi pozitíva samotného výkonu profesie patria skúsenosti, vedomosti, sebarealizácia a prax. Menované atribúty sú dokonca uprednostnené pred finančným ohodnotením s náskokom 17\%. Riešenia respondenti vidia v skrátení pracovnej doby a v zavedení väčších pracovných benefitov (71\%). 29\% respondentov si neželá žiadnu zmenu. Ako najväčší problém vnímame nedostatočnú podporu zamestnancov zo strany zamestnávatel’a v oblastiach riešenia problémových situácií na pracovisku, ako aj nedostatočného vytvárania benefitov a podpory v rámci programov pre rodiny. V budúcnosti by bolo vhodné merat' danú problematiku prostredníctvom väčšej vzorky a prepracovanejšieho štatistického merania, čo by mohlo priniest' d’alšie validnejšie výsledky.
\end{abstract}

Klúčové slová: rodina, rodina - práca, konflikt, konflikt práce a rodiny, Slovensko, benefity

\section{ÚVOD}

Výskumná štúdia identifikuje dôvody vzniku konfliktov, ich prelínanie s pracovným a rodinným životom a pokúša sa načrtnút' možnosti riešenia krízových situácií. Ďalej sa zameriava na príčiny vzniku konfliktov z pohl'adu zamestnancov a zamestnávatel’ov: ako si zamestnávatelia vážia svojich zamestnancov v rôznych odvetviach práce, ako im pomáhajú, čo sú ochotní vykonat' v ich prospech a aké benefity im ponúkajú. 0 konflikte môžeme hovorit' ako o komplexnom probléme. Ak sa vyskytne, ovplyvňuje celú rodinu i oblast’ práce (Kozubík, Lehoczká, 2014; MacDermid, 2005; Odrášková, Kozubík, Odráška, 2016; Rác, Kozubík, 2012; Rác, Kozubík, Mátel, 2016; Vanková, Kozubík, 2012;). Štúdium vzájomnej previazanosti oblastí práce a rodiny má v západných krajinách ovel'a dlhšiu tradíciu než na poli slovenskej sociálnej práce. So zvyšujúcim sa počtom dvoj príjmových rodín, začali psychológovia v USA intenzívne skúmat' súvislosti pracovného a rodinného života. Predpokladom vedeckého bádania bolo okrem iného zavedenie nových pojmov týkajúcich sa danej oblasti do odbornej psychologickej terminológie. Problematike konfliktu práce a rodiny sa začala venovat' väčšia pozornost' v 60. rokoch 20. storočia, kedy Kahn so spolupracovníkmi sformulovali teóriu rolí, v ktorej je rolový konflikt definovaný ako súčasné pôsobenie dvoch alebo viacerých tlakov, pričom vyhovenie jednému st'ažuje vyhovenie druhému (Kahn, 1964). Na základe tejto teórie bola sformulovaná prvá konkrétna definícia konfliktu práce a rodiny: „Konflikt práce a rodiny je forma konfliktu rolí, v ktorom tlaky pracovných a rodinných úloh sú po istej stránke vzájomne nekompatibilné“ (Greenhaous, Beutell, 1985). Práca týchto autorov sa stala najcitovanejšou v oblasti výskumu práca verzus rodina. Uvádzajú v nej tri typy konfliktov (Mason, 2002):

- $\quad$ konflikt vyplývajúci z (nedostatku) času (time-based conflict),

- $\quad$ konflikt vyplývajúci z (nadmerného) napätia (strain-based conflict),

- $\quad$ konflikt vyplývajúci zo správania (behavior-based conflict). 
Ranné výskumy týkajúce sa konfliktu práce a rodiny nebrali do úvahy smer konfliktu a teda, či práca negatívne zasahuje do rodiny alebo naopak. Boli to tzv. unidimenzionálne výskumy. Neskoršie práce už začali rozlišovat' smer konfliktu a tak vznikla nová teória, tzv. dvojdimenzionálna. Ten však nebola venovaná dostatočná pozornost'. Gutek et al. (1991) uvádzajú, že konflikt práce a rodiny má dva smery a to:

- zasahovanie práce do rodiny (tzv. work-to-family conflict alebo work interference with family) - požiadavky v pracovnej oblasti sú také vysoké, že bránia adekvátnemu napĺn̆aniu požiadaviek v rodinnej sfére;

- zasahovanie rodiny do práce (tzv. family-to-work conflict alebo family interference with work) - je v podstate opakom predchádzajúceho konfliktu, kedy má človek pocit, že rodinné povinnosti mu prekážajú pri napíňaní pracovnej roly. Hoci zasahovanie práce do rodiny a rodiny do práce sú dvoma odlísitel’nými dimenziami, zároveň spolu do istej miery súvisia, pretože tvoria jeden konštrukt.

Eagle, Miles a Icenogle (1997) sa stotožňujú s Gutekovou (1991) a taktiež definujú konflikt práce a rodiny $\mathrm{v}$ dvoch základných rovinách. Vnímajú to tak, že $\mathrm{v}$ prvej ide o zasahovanie práce do rodiny, kedy človek pocit’uje požiadavky pracovnej role tak vysoké, že bránia adekvátnemu napíňaniu požiadaviek $\mathrm{v}$ rodinnej sfére. $\mathrm{V}$ druhej rovine rodina svojimi nárokmi zasahuje do pracovných rolí.

V Slovenskej republike absentujú poznatky o tom, aké reálne možnosti riešenia majú zamestnanci v konfliktných situáciách na pracovisku; kto im pomáha tak, aby sa zabránilo prenosu do rodinného života a konflikt sa nerozširoval. Doposial' máme vo všeobecnosti známe benefity, ktoré môžu ponúkat' zamestnávatelia svojim pracovníkom, no chýba nám reálny pohl’ad na to, ktoré sa priamo v skutočnosti uplatňujú. Dnes sa so záujmom skúmat’ konflikty práce a rodiny môžeme stretnút' v rôznych zahraničných štúdiách. Napríklad v porovnaní troch krajín: India, Peru a Španielsko, kde tento konflikt práce a rodiny sledovali na zamestnancov obchodnej organizácie. Autori prišli na to, že v Peru a Španielsku je vel'ká podpora zo strany manažmentu, čo naopak v Indii chýba. Pri riešení konfliktov sa neukázal rozdiel v rámci rodu, no naopak rozhodoval vek respondenta. Čím bol starší, tým viac dbal o to, aby sa konflikty neprenášali na rodinu (Agarwala, Arizkuren-Eleta, Del Castillo, 2014). Štúdie riešia i konflikt práce a rodiny vzhl'adom k individualizmu (Brough, O’Driscoll, 2015; Brough, Timms, O’Driscoll, 2014). Zaujala nás taktiež štúdia zameraná na pracovisko zdravotných sestier, vplyv práce na ich rodinný život a taktiež aj na zdravotný stav. Odporúčania navrhujú, aby sa znížili emočné nároky a zlepšilo hodnotenie ich práce (Elfering, A., Häflinger, 2017; Mauno, S., Ruokolainen, 2017). Stretli sme sa so štúdiami, ktoré porovnávali konflikt práce a rodiny na základe rodovej rovnosti v Európe (Hagqist, 2017), pri konflikte práce a rodiny u učitel'ov (Houlfort, Philippe, Bourdeau, Leduc, 2017), ale aj policajtov v Indii, kde bol konflikt prenosu práce a rodiny založený na pracovnej vypätosti a nárastom stresu (Lambert et al., 2016). Stretli sme sa aj s výskumom, kde pri situácii konfliktu práca-rodina bol prítomný supervízor, pričom ženy zvládali toto riešenie lepšie ako muži (Li, Bagger, Cropanzano, 2016). V neposlednom rade sme prišli do kontaktu aj so štúdiami, ktorých respondenti boli hasiči, kde na porovnanie s predchádzajúcou štúdiou s policajtmi, predchádzala konfliktom pracovná emočná vypätost' (O’Neill, 2017; Smith, Hughes, DeJoy, 2017). Podnetným výskumom bola i komparatívna štúdia zamestnaných a nezamestnaných v kontexte vplyvu na rodinu (Reichl, Leiter, Spinath, 2014). Medzi aktuálne témy patrí i časový manažment, ktorý pôsobil stresujúco na zamestnancov a tí si tento stres prenášali domov (Timms, Brough, Siu, 2015; Yi, Kwan, Hu, Chen, 2017). Na základe uvedeného možno konštatovat', že konflikt medzi rodinou a prácou prekračuje hranice krajín a kontinentov. Na Slovensku však podobné výskumy absentujú. Našim ciel'om bolo vstúpit' do tohto vzt'ahu a priniest' informácie o tunajšom prostredí. Zaujímalo nás, aké sú jednotlivé faktory, ktoré ovplyvňujú proces prenosu 
práce do oblasti rodiny. Snažili sme sa nájst' odpovede na otázky: Aké sú možnosti zmeny na pracovisku? Aké sú pozitíva prostredia práce na rodiny?

\section{METÓDY}

\section{Výberový súbor}

Pre potreby nášho výskumu sme považovali za správne zvolit' zámerný výber subjektov. Základnou zložkou výskumného súboru boli pracujúci v manželskom zväzku. Výskumnú vzorku tvorilo 130 respondentov, z nich bolo 82 žien a 48 mužov.

\section{Zber dát}

Ked'že ciel'om nášho výskumu je zistit' súvislost' medzi faktormi konfliktu práce do oblasti rodiny a možnými riešeniami, rozhodli sme sa zvolit' kvantitatívnu metódu zberu dát: neštandardizovaný dotazník. "Je to najfrekventovanejšia metóda zist'ovania údajov. Táto písomná forma riadeného rozhovoru patrí medzi exploračné metódy. Používa sa na získanie vel'kého množstva informácií, od relatívne vel'kého počtu respondentov, za krátky čas. Frekventovanost' je často daná (zdanlivo) l'ahkou konštrukciou dotazníka. Dotazník má mat' premyslenú štruktúru" (Kalous, 1983). Nakol'ko výskumnú vzorku nášho výskumu tvoril vysoký počet respondentov považujeme dotazník za najideálnejšiu metódu zberu dát pre daný výskum. Dotazník bol zostavený z 15 otázok.

\section{Analýza údajov}

V auguste 2016 sme začali s preštudovaním odbornej literatúry potrebnej kvytvoreniu terminologickej základne. V mesiacoch október - december 2016 sme zosumarizovali teoretické východiská. Nasledovalo zostavenie dotazníka, ktorý bol nástrojom zberu dát. V januári 2017 sme začali oslovovat' potencionálnych respondentov a následne začal zber dát. $\mathrm{Na}$ spracovanie výsledkov výskumu a ich interpretáciu sme si stanovili časové rozpätie február - apríl 2017. Neštandardizovaný dotazník zložený mapoval nominálne hodnoty jednotlivých premenných: pohlavie, vzdelanie, dížka praxe v pracovnom procese a pod. Naše výsledky sme vyhodnocovali jednoduchými početnost’ami v percentuálnom vyjadrení. Zber sme rozdelili na tri časti. V prvej fáze sme sa zamerali na jednotlivé faktory, ktoré ovplyvňujú proces prenosu práce do oblasti rodiny. Ciel'om druhej bolo zistit' pozitíva a prínosy práce na rodinný život. Ciel'om tretej fázy výskumu bolo zistit' možnosti zmien na pracovisku. Jednotlivé výsledky uvádzame v prehl'adných grafov a príslušných tabul'kách.

\section{VÝSLEDKY}

\subsection{Jednotlivé faktory, ktoré ovplyvňujú proces prenosu práce do oblasti rodiny}

Na objasnenie vzt’ahu medzi faktormi konfliktu práce do oblasti rodiny a možnými riešeniami sa zapojilo 130 respondentov. Vzorku tvorilo $36 \%$ mužov a $64 \%$ žien. 74 \% zúčastnených mužov má stredoškolské vzdelanie, pričom z celkového počtu žien 83 , má stredoškolské vzdelanie len 45 \%. Z grafu možno vidiet', že najväčšie zastúpenie vo výskume mali teda ženy s vysokoškolským vzdelaním, ktoré tvorili 35 \% z celkového počtu respondentov. 


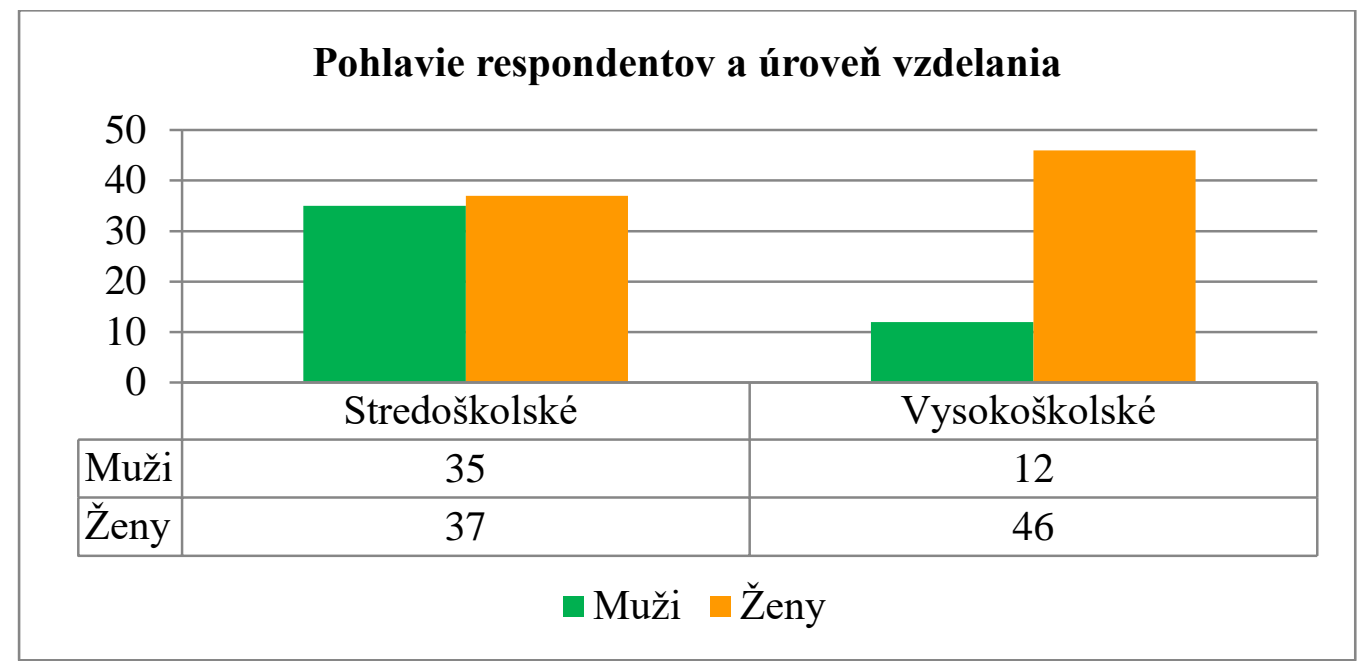

Obrázok 1 Pohlavie a úroveň vzdelania respondentov

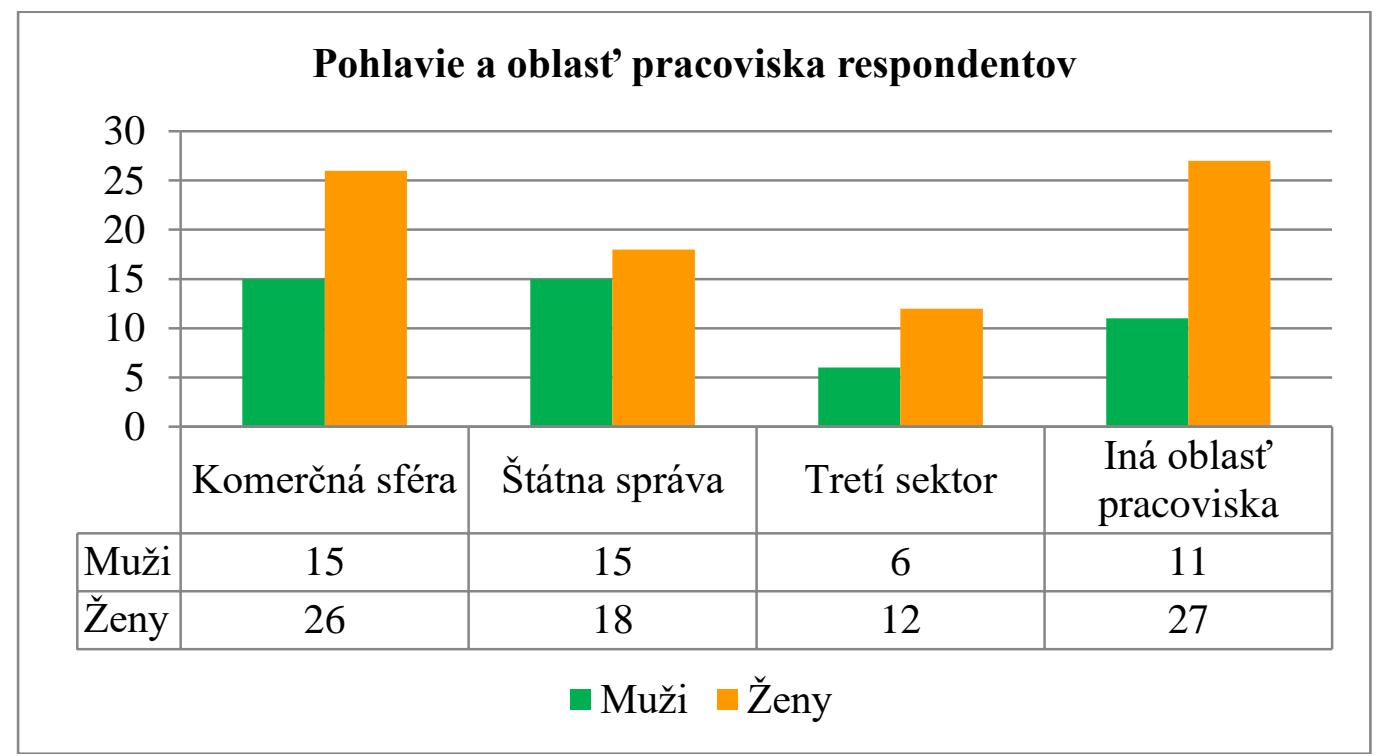

Obrázok 2 Pohlavie a oblast' pracoviska respondentov

Z celkového počtu respondentov pracuje až 32 \% l'udí v komerčnej sfére. V tejto sfére pracuje 26 celkovo zúčastnených žien, čo $\mathrm{v}$ porovnaní s mužmi predstavuje $63 \%$. Pre porovnanie $\mathrm{z}$ celkového počtu žien, tvorí komerčnú sféru 26 zúčastnených, čo predstavuje taktiež ako u mužov $32 \% \mathrm{z}$ celkového počtu a štátnu správu predstavuje $22 \%$ žien. $14 \%$ l'udí pracuje v tret'om sektore a $29 \%$ zúčastnených označilo možnost' iné. Po týmto pojmom boli na základe rozboru odpovedí zahrnuté samostatne zárobkovo činné osoby - tzv. podnikatelia. 


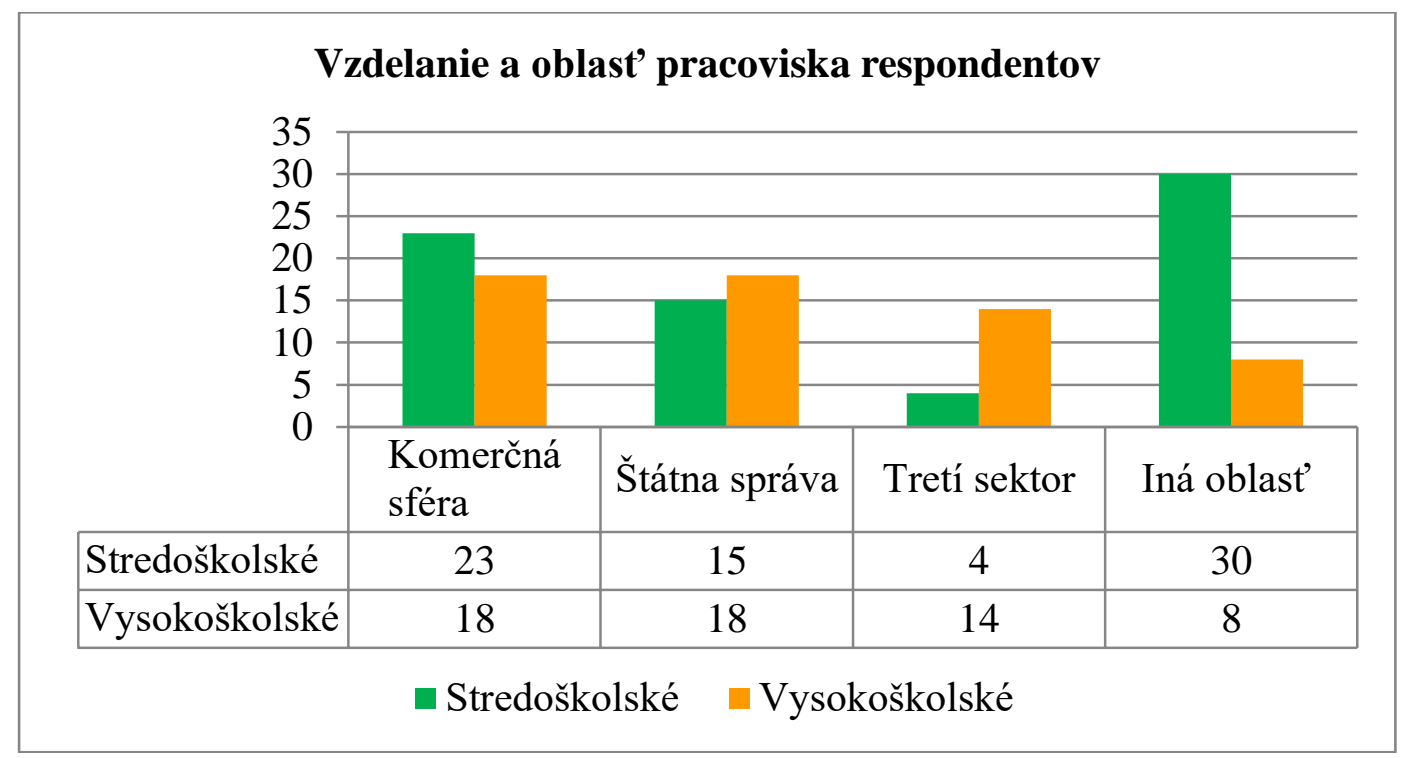

Obrázok 3 Dosiahnuté vzdelanie a oblast' pracoviska respondentov

Pri otázke: "Kto Vám pomáha pri riešení konfliktov práce a rodiny?" mali respondenti k dispozícii nasledovné možnosti: súd, mediátor, odborný pracovník - poradca, rodina, priatelia a taktiež „nemám sa na koho obrátit'“. Z celkového počtu 185 odpovedí sa najčastejšie objavovala pomoc rodiny, čo tvorí 36 \% odpovedí. Druhé miesto preberajú priatelia, ktorí tvoria 32 \% odpovedí. Tretie miesto s dosiahnutými $24 \%$ bola odpoved', že respondentom nikto nepomáha pri riešení týchto konfliktov. Ôsmim percentám pomáha pri riešení mediátor, poradca a v položke iné bola $\mathrm{v}$ dvoch prípadoch uvedená odpoved' „supervízor“.

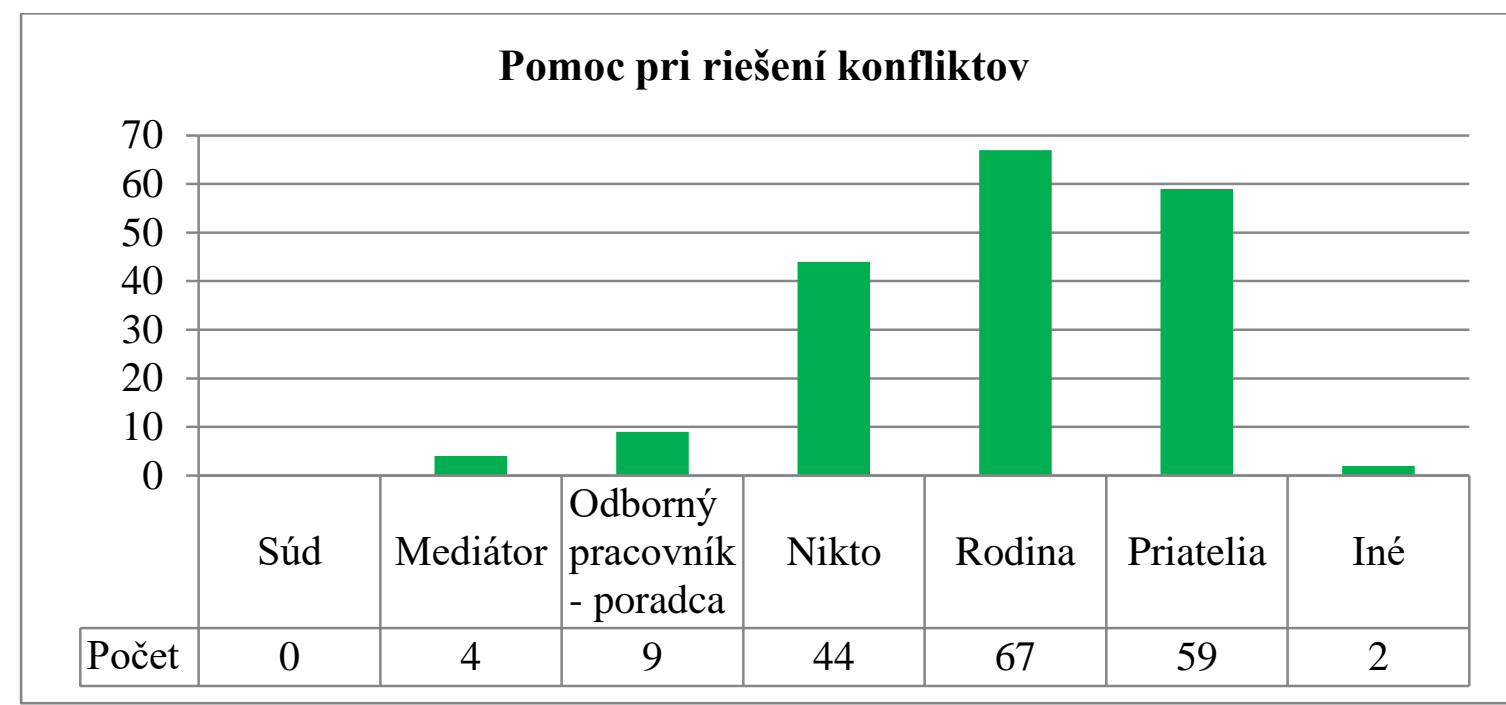

Obrázok 4 Pomoc pri riešení konfliktov

Respondentov sme sa d’alej pýtali na spôsob akým riešia konflikt. Celkovo sme zaznamenali 197 zvolených spôsobov riešenia konfliktov. Najčastejším spôsobom riešenia konfliktu u mužov aj 
žien je kompromis. Ten tvorí 40 \% celkových odpovedí. U mužov tvorí vol’ba kompromisu $46 \%$, u žien je to $37 \%$. Najmenej respondentov rieši konflikty súperením, čo predstavuje len $1 \%$ celkových odpovedí. Na druhom mieste z pohl'adu mužov je riešenie konfliktu prispôsobením sa, čo v našom prípade predstavuje $22 \%$ z počtu mužov. Prispôsobenie sa u žien ako spôsob riešenia konfliktu uplatňuje $26 \%$ opýtaných.

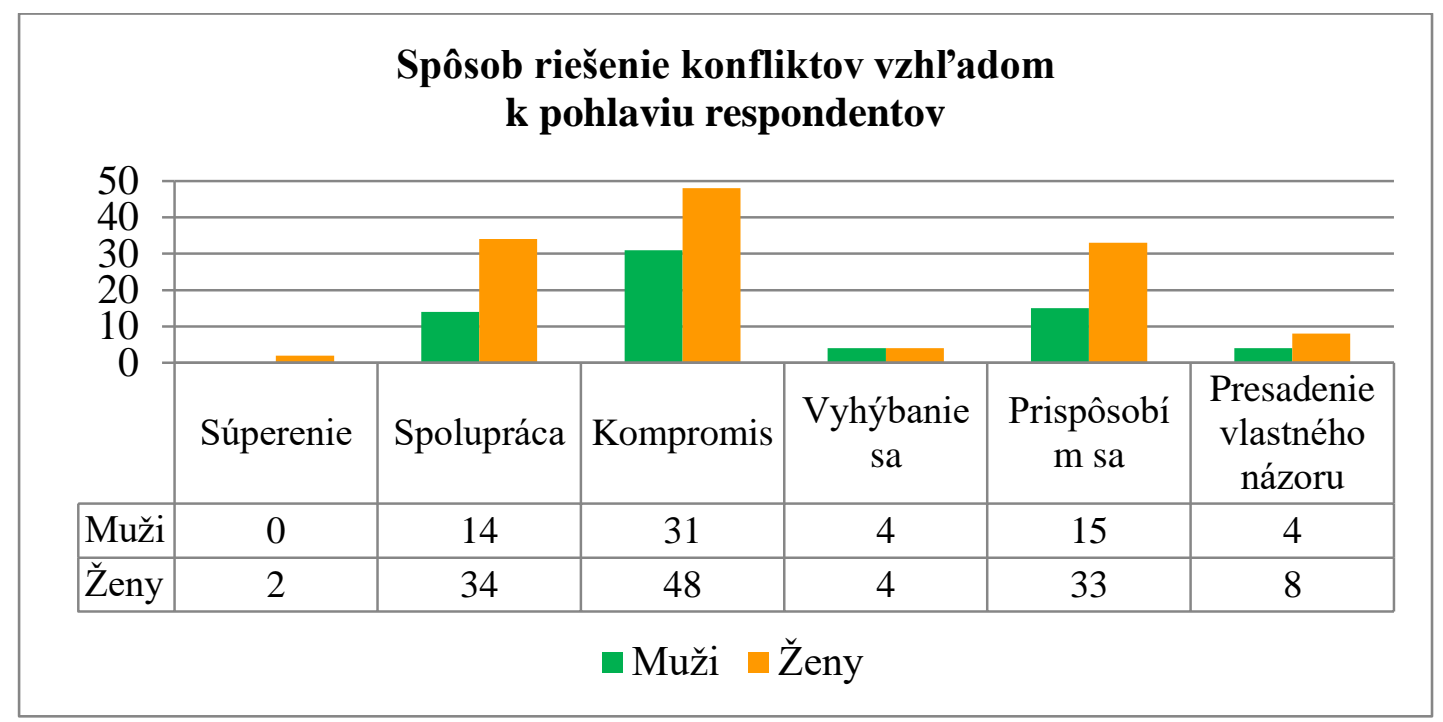

Obrázok 5 Spôsob riešenia konfliktov vzhl’adom k pohlaviu respondentov

Otázku zameranú na riešenie problémovej situácie na pracovisku prirad'ujeme $\mathrm{k}$ faktorom, ktoré ovplyvňujú proces prenosu práce do oblasti rodiny. Celkový počet označených možností bol 175. Najčastejšou možnost'ou riešenia problému bol rozhovor s manželom alebo manželkou, čo pre náš výskum predstavuje $33 \%$. Možnost' "snažím sa to vyriešit' sám" označilo $23 \%$ a riešenie problému nervozitou a napätím označilo $20 \%$, respondentov. "Lahko vybuchne" $13 \%$ respondentov.

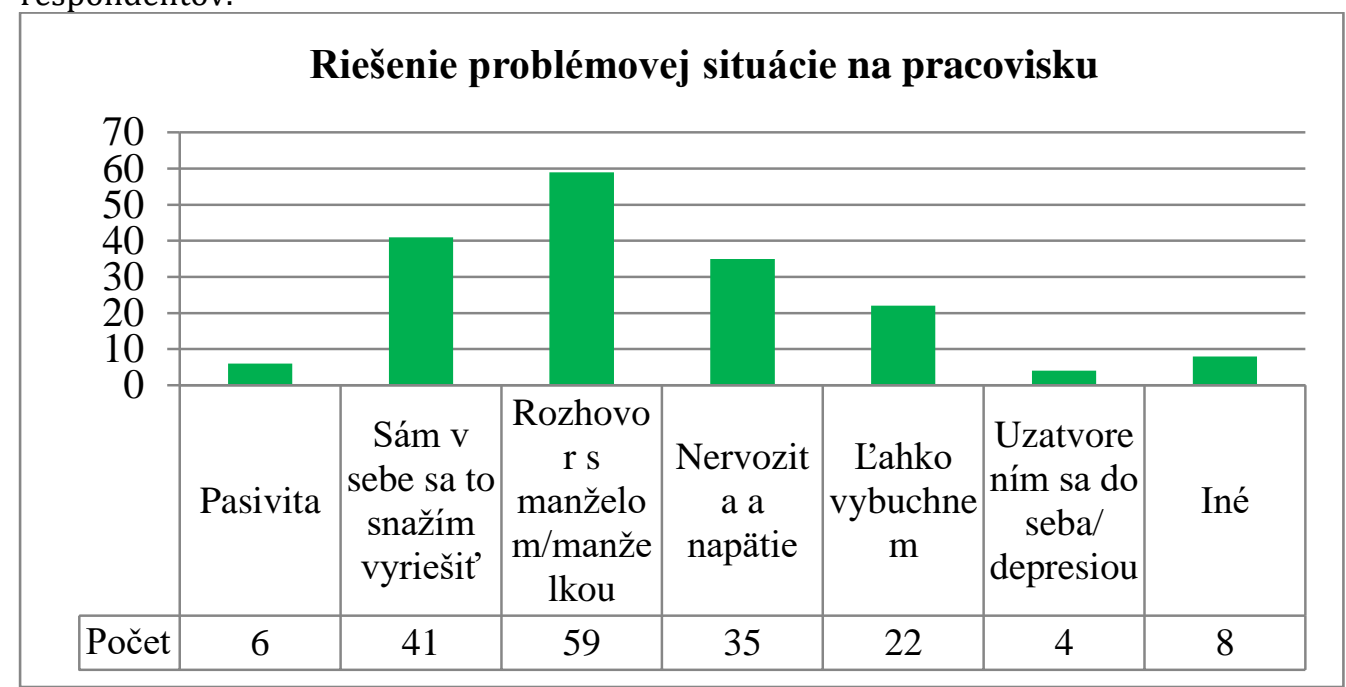

Obrázok 6 Riešenie problémovej situácie na pracovisku 


\subsection{Pozitíva prostredia práce na rodiny}

Druhým naším čiastkovým ciel'om bolo zistit' pozitíva vplyvu pracovného prostredia práce na rodinu. Na základe uskutočneného výskumu sme dospeli k nasledovným výsledkom:

Ciel'om škálovanej položky číslo 9 sme sa zamerali na zistenie, či respondenti vnímajú pozitívny vplyv práce na ich rodinný život. Tento vplyv sme porovnali na základe toho, v akej oblasti naši respondenti pracujú. Z celkového počtu respondentov bolo najpočetnejšou odpoved'ou to, že respondenti súhlasia s tvrdením, že práca má pozitívny vplyv na rodinu a to s počtom až $36 \%$. Druhú priečku v najväčšom zastúpení dosiahla neutrálna odpoved' "neviem" s 31 \%. Snahou bolo zistit’ názor respondentov ako sú vnímajú tvrdenie, že práca má pozitívny vplyv na ich rodinný život. Súhlas s týmto tvrdením vyslovilo v komerčnej sfére 39 \%, v štátnej správe to bolo až 58 \%, v rámci tretieho sektora to bolo $44 \%$ a v inej oblasti to predstavuje $11 \%$.

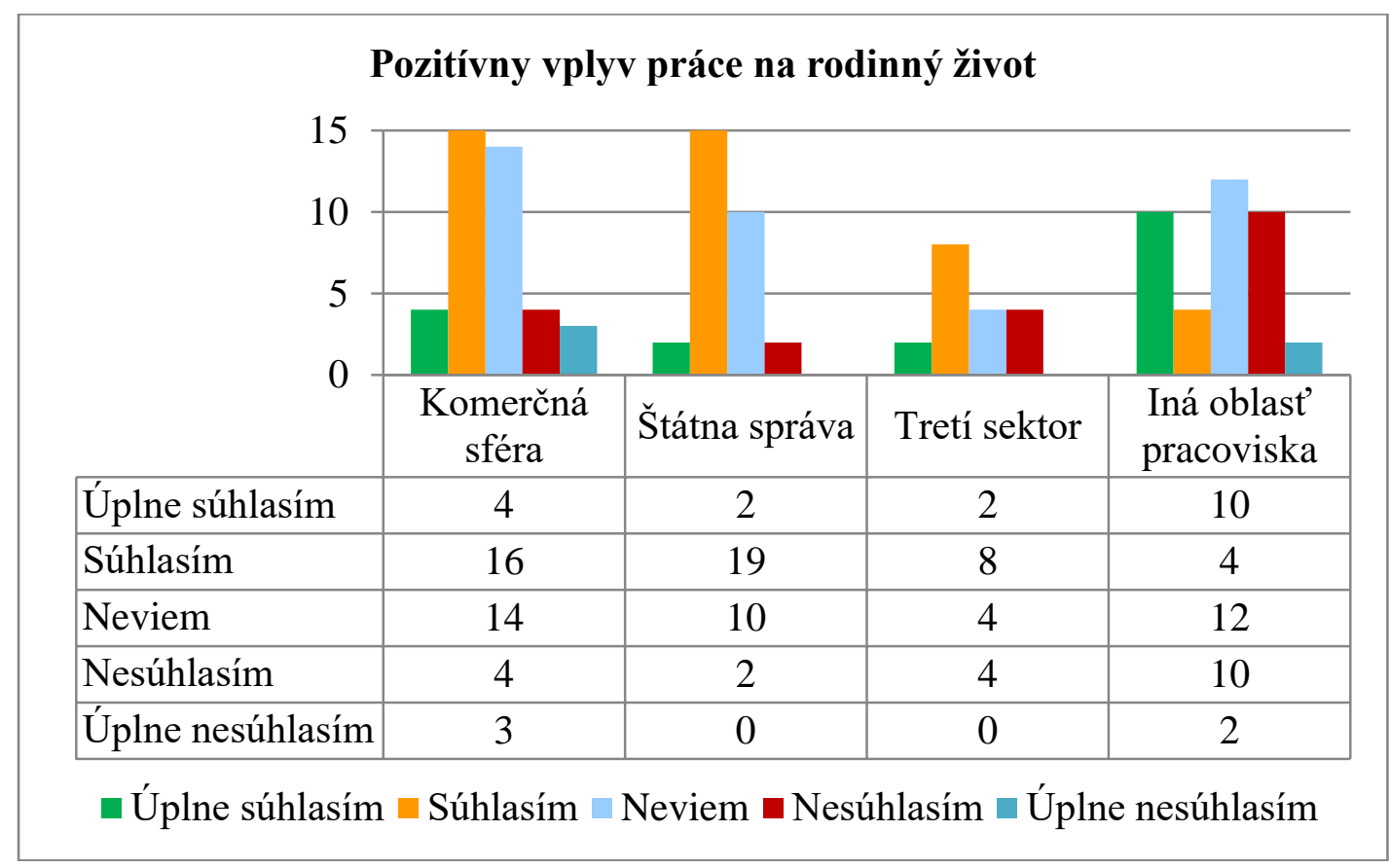

Obrázok 7 Pozitívny vplyv práce na rodinný život

Z celkového počtu respondentov bolo najpočetnejšou odpoved'ou to, že respondenti nesúhlasia s tým, že práca má negatívny vplyv na rodinu a to s počtom až $35 \%$. Najväčšia miera nesúhlasu je prítomná v komerčnej sfére, čo predstavuje $44 \%$, taktiež vysoká miera nesúhlasu s počtom $42 \%$ je prítomná v štátnej správe. 
Negatívny vplyv práce na rodinný život

\begin{tabular}{|c|c|c|c|c|}
\hline & $\begin{array}{l}\text { Komerčná } \\
\text { sféra }\end{array}$ & Štátna správa & Tretí sektor & $\begin{array}{l}\text { Iná oblast' } \\
\text { pracoviska }\end{array}$ \\
\hline Úplne súhlasím & 5 & 0 & 0 & 2 \\
\hline Súhlasím & 8 & 6 & 4 & 7 \\
\hline Neviem & 10 & 11 & 6 & 17 \\
\hline Nesúhlasím & 18 & 14 & 8 & 6 \\
\hline Úplne nesúhlasím & 0 & 2 & 0 & 6 \\
\hline
\end{tabular}

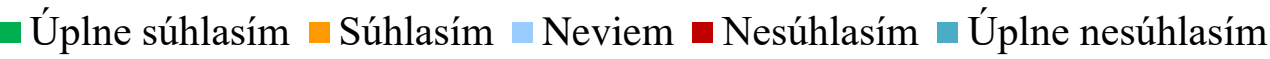

Obrázok 8 Negatívny vplyv práce na rodinný život.

Medzi pozitíva pracovného prostredia na rodiny prirad'ujeme aj možnosti pomoci vzhl'adom na oblast' pracoviska. Našim respondentom sme v rámci odpovedí poskytli niekol'ko alternatív: supervíziu, mediáciu, psychológa, sociálneho pracovníka, odbory, finančného poradcu a taktiež sme k týmto možnostiam priradili aj sociálny program pre rodinu a deti, možnost' práce doma a flexibilný pracovný čas. $\mathrm{K}$ týmto možnostiam sme priradili príslušné oblasti pracoviska. $\mathrm{V}$ komerčnej sfére sa objavila nulová pomoc mediácie, d’alej sa nám objavili 4 prípady supervízie, 2 prípady pomoci psychológa, sociálneho pracovníka a finančného poradcu. $V$ štátnej správe sa $s$ najvyšším počtom pomoci objavuje pomoc psychológa a sociálneho pracovníka. Respondenti pracujúci v tret’om sektore sa stretávajú so všetkými uvedenými možnost'ami pomoci okrem pomoci odborov a sociálneho programu pre rodiny.

\section{Možnosti pomoci vzhl'adom na oblast' pracoviska}

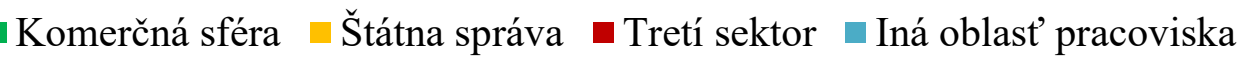
15

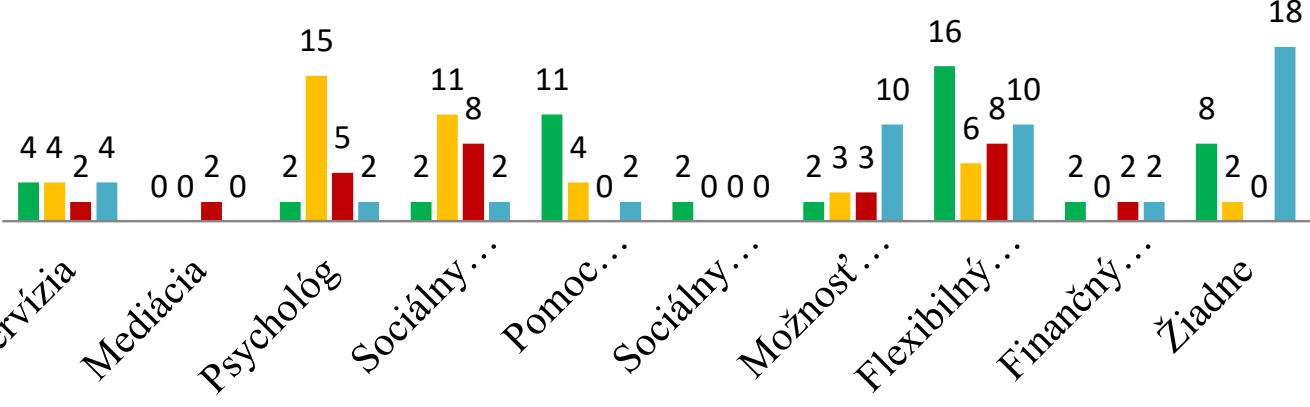

Obrázok 9 Možnosti pomoci vzhl'adom na oblast' pracoviska 


\section{Možnosti zmeny na pracovisku}

V tejto časti výskumu sme sa prostredníctvom dotazníka zist'ovali, aké zmeny na pracovisku by naši respondenti uvítali. Taktiež nás zaujímalo aké benefity poskytuje zamestnávatel'.

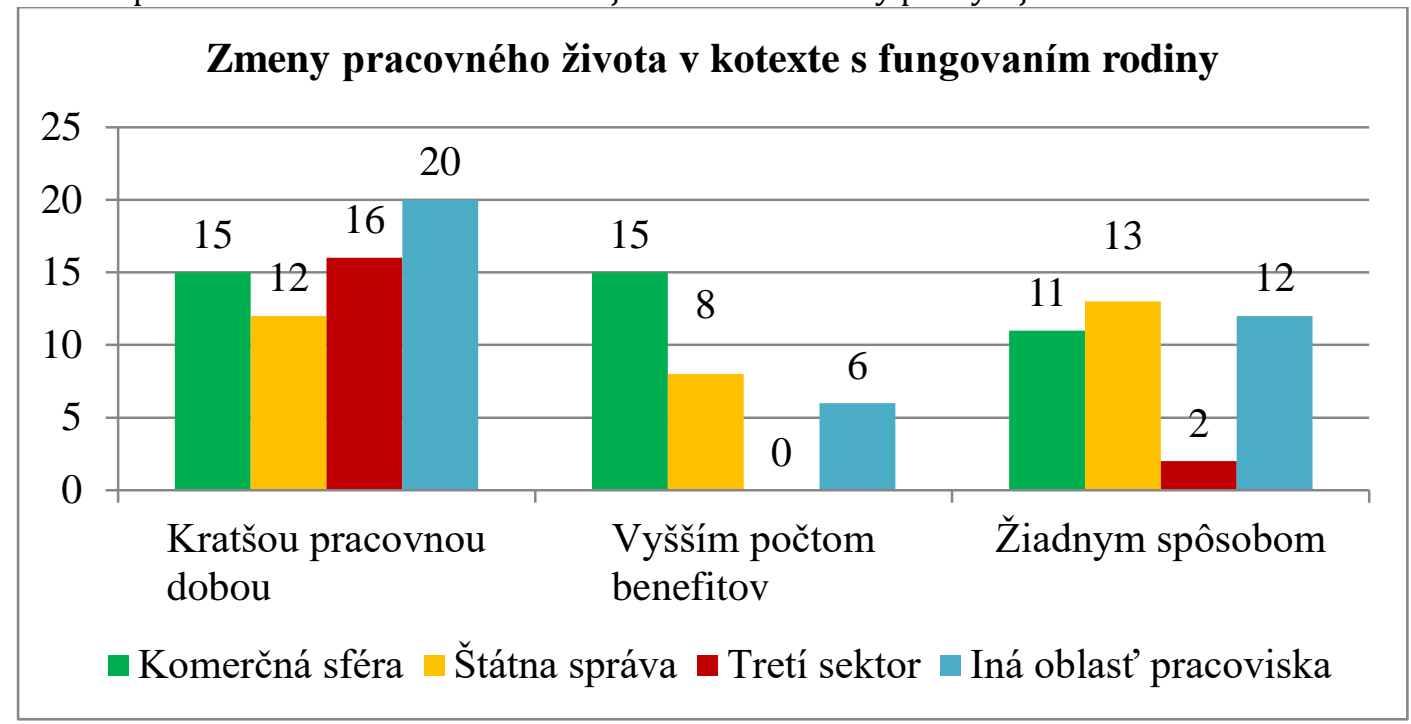

Obrázok 10 Zmeny pracovného života v kontexte s fungovaním rodiny.

V dotazníku sme d’alej respondentom položili otázku v čom by sa mal zmenit’ ich pracovný život, aby bolo zabezpečené lepšie fungovanie rodiny. Nechali sme priestor i pre tvorbu vlastných odpovedí, ktoré sme pri vyhodnocovaní kategorizovali. Zo všetkých odpovedí sa nám podarilo identifikovat' tri kategórie. Išlo o kratšiu pracovnú dobu, vyšší počet benefitov a napokon by respondenti nemenili, nepriali si zaviest' zmeny.

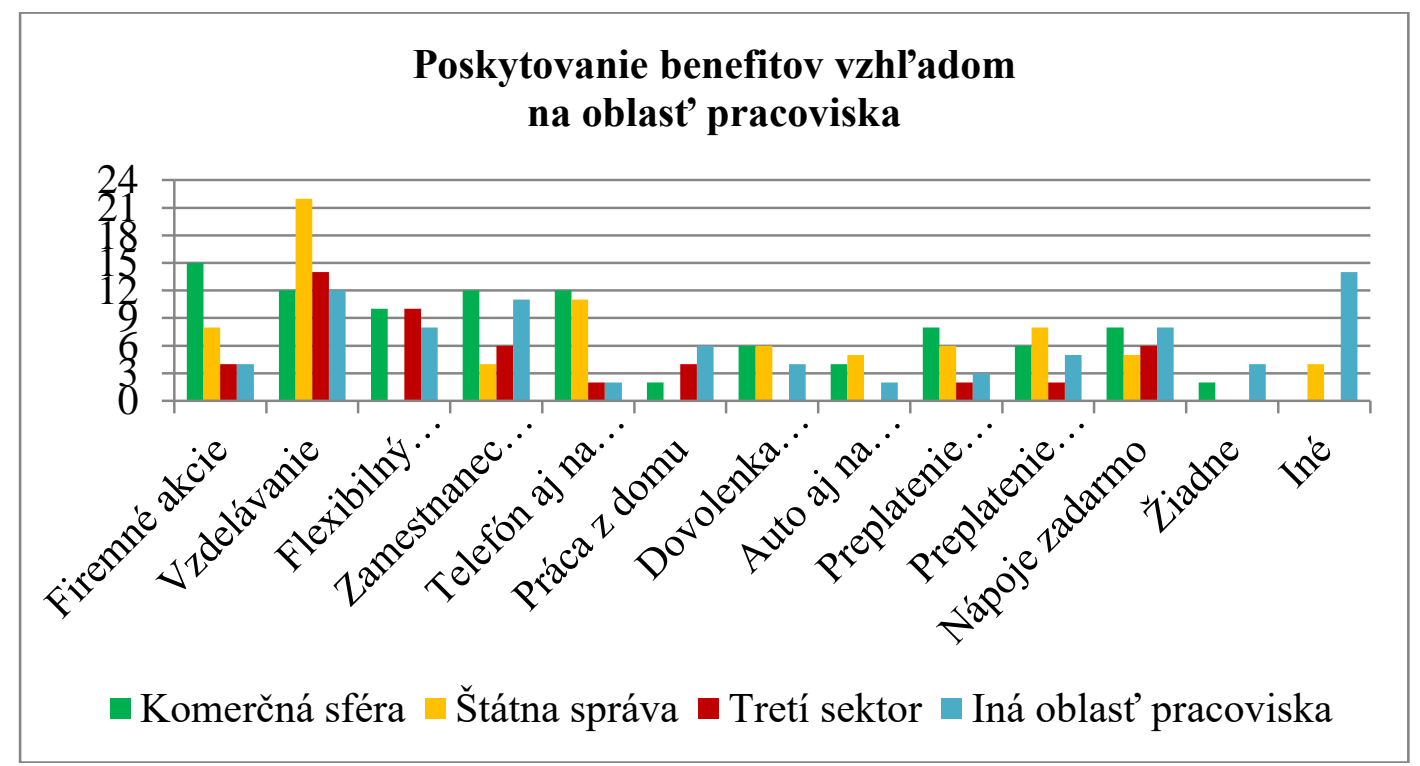

Obrázok 11 Poskytovanie benefitov vzhl'adom na oblast' pracoviska. 


\section{DISKUSIA}

Ciel'om výskumu bolo identifikovat' faktory vstupujúce do konfliktného vzt'ahu rodina verzus práca. Hlavný ciel' práce sme rozdelili na tri časti. V rámci prvého čiastkového ciel'a sme sa snažili identifikovat' jednotlivé faktory, ktoré ovplyvňujú proces prenosu práce do oblasti rodiny. Prostredníctvom druhého čiastkového ciel'a sme sa pokúsili zistit' pozitívne atribúty vplyvu pracovnej oblasti na oblast' rodinnú. Posledný ciel' mapoval možnosti zmien na pracovisku.

\section{Limity}

Vo výskume sme použili kvantitatívnu metódu zberu dát: neštandardizovaný dotazník. Upustili by sme od formulácie otázky s možnost'ou otvorených odpovedí. Vyhli by sme sa tak možným chybám pri identifikovaní kategórií. Za zváženie stojí kombinácia výskumných nástrojov: okrem dotazníka, by sme radi výpovede informátorov mapovali prostredníctvom interview. Po obsahovej stránke vidíme aj negatíva v škálovaných otázkach, ked’že častou bola práve neutrálna odpoved'. Najväčším nedostatkom nami realizovaného výskumu bola absencia hypotéz a ich štatistického zist'ovanie. Naše výsledky podávajú stručný popis skúmanej problematiky.

\section{Odporúčania pre prax}

Z dosiahnutých výsledkov odporúčame jednotlivcom nebát' sa komunikovat' o svojich problémoch s blízkou osobou (manžel/manželka, partner/ka, priatel', a pod.), resp. s odborným pracovníkom ( psychológom, sociálnym pracovníkom, supervízorom, a pod.). V dnešnej dobe, ked' je bežné prelínanie pracovného života s rodinným, je dôležité stanovit' si hranice. Vel'a konfliktov je následkom drobných nedorozumení, vypätosti z práce, stresu, nedostatku času alebo zlého plánovania denného harmonogramu. Považujeme za dôležité hovorit' o sociálnej opore v zamestnaní. Je úlohou zamestnávatel'ov zvýšit' pozornost' v oblasti riadenia. Zamestnávatel' by mal dôsledne zvážit’ mieru poskytovania sociálne opory spôsobom, aby nevytváral nárast vzniku konfliktu medzi pracovným a rodinným prostredím. Mal by podporovat' tímovú prácu, ktorá umožňuje spolupracovníkom lepšiu sociálnu interakciu, a tým vytvárat' lepšie pracovné prostredie. Odporúčame zamestnancom, ktorí sú nespokojní so svojou pracovnou dobou, aby sa to pokúsili riešit’ so svojimi zamestnávatel'mi. Samozrejme, že v niektorých pracovných oblastiach to nie je možné, $v$ týchto prípadoch odporúčame pomoc človeka, ktorý priamo komunikuje $\mathrm{s}$ nadriadeným (napr. pomoc odborov) a mohol by dopomôct' ku kompenzácii formou zamestnaneckých výhod, benefitov. Na základe výskumu Greenhausa a Friedmana (2000) ženatí muži dosahujú vyššie pozície $\mathrm{v}$ organizáciách v porovnaní so slobodnými mužmi, zároveň sú spokojnejší so svojou kariérou. Dôvodom prečo sú ženatí muži úspešnejší, je skutočnost', že manželstvo pôsobí autoritatívnejšie. Podobne to platí aj pre mužov, ktorí sú otcami. Otcovstvo má podl'a autorov pozitívny vplyv na kariéru. Čo sa týka žien, manželstvo nijakým spôsobom neovplyvňuje ich kariéru, ani nenapomáha k úspechu. Taktiež autori tvrdia, že podobný efekt na kariéru platí aj na materstvo. Podobne zameranému výskumu sa plánujeme venovat' v budúcnosti. Naše zistenia potvrdzujú, že spokojní zamestnanci sú predpokladom úspešného podniku. Spokojnost' zamestnancov je úzko spojená s benefitmi, ktoré im zamestnávatel' poskytuje. Niektoré tieto výhody máme sú na Slovensku zakotvené v tzv. kolektívnej zmluve, ktorú vypracováva každé vedenie podniku spolu s odborovou organizáciou jeden krát ročne. Odporúčame zamestnancom, aby sa o tieto kolektívne zmluvy zaujímali a pozorne si ich prezreli, aby vedeli na aké sociálne programy pre seba a rodinu a výhody majú nárok. Jedným z takýchto sociálnych programov tvorí sociálny fond, ktorý dáva zl'avy na rôzne aktivity: šport, domáce a zahraničné rekreácie a kultúrne podujatia. Tiež poskytuje pôžičky, ktoré tvoria asi $40 \% \mathrm{z}$ 
celkového sociálneho fondu. Pôžičky sa môžu využit' na zariadenie bytu, rekonštrukciu a odkúpenie bytu. Medzi príspevky na rekreácie pre zamestnancov patria detské tábory, domáce rekreácie, zahraničné rekreácie, wellness pobyty, relaxačné pobyty, regeneračné pobyty $\mathrm{v}$ zariadeniach so štatútom liečebných kúpel'ov. Taktiež d'alšie príspevky, ktoré sú prínosné pre rodinu. K nim zarad'ujeme napríklad príspevok pri narodení diet’at’a, príspevok pri dlhodobej PN, mimoriadnu sociálnu výpomoc, príspevok pri prvom riadnom odchode do starobného, predčasného alebo invalidného dôchodku, podporu pri úmrtí, príspevok pri pracovnom jubileu, príspevok bezplatným darcom krvi, príspevok na stomatologické výkony (dentálna hygiena, vstupná prehliadka a kontrolné komplexné vyšetrenie) u zmluvného zubára, multivitamíny, pitný režim. Tieto všetky spomenuté príspevky v rámci benefitov a sociálnych programov na podporu zamestnanca a jeho rodinu pomáhajú v minimalizovaní pracovných konfliktov a prenosu do rodinného prostredia.

\section{ZÁVER}

Ciel'om nášho výskumu bolo analyzovat' súvislosti v kontexte: práca verzus rodina a navrhnút' riešenia tohto, často konfliktného, vzt’ahu. Najvýznamnejšou zmenou, ktorú odporúčame je kratšia pracovná doba, ktorá by znamenala vyššiu mieru vol'ného času na osobné aktivity, výchovu detí, trávenie spoločných chvíl' s rodinou a pod. Nemenej dôležitý vyšší počet benefitov, ktorý by mal ponúknut' zamestnávatel'. Identifikované boli predovšetkým: flexibilný pracovný čas, kratšia pracovná doba, sociálne programy pre rodinu a deti, špeciálne výhody smerom $\mathrm{k}$ rodine. Problematika konfliktu práce a rodiny by si zaslúžila i v budúcnosti d'alšie skúmanie, najmä v oblasti priemyslu a prílevu nových pracovných síl z Ukrajiny, Srbska a iných krajín.

\section{LITERATÚRA}

Agarwala, T, Arizkuren-Eleta, A, \& Del Castillo, E. (2014). Influence of managerial support on work-lifeconflict and organizational commitment: Aninternational comparison for India, Peru and Spain. The International Journal of Human Resource Management.

Brough, P., \& O’Driscoll, M. P. (2015). Integratingwork and personallife. In R. J. Burke, K. M. Page \& C.L. Cooper (Eds.), Flourishing in Life, Work, and Careers: Individual Wellbeing and Career Experiences ( pp. 377-394). Cheltenham: Edward Elgar Publishing.

Brough, P, Timms, C, \& O’Driscoll, M. (2014). Work-lifebalance: A longitudinal evaluation of a new measure across Australia and New Zealand workers. International Journal of Human Resource Management, 25(19), 2724-2744.

Eagle, B. W., Miles, E. W., \& Icenogle, M. L. (1997). Interrole Conflicts and the Permeability of Work and Family Domains : Are There Gender Differences? Journal of Vocational Behavior, 50, 168-184.

Elfering, A., \& Häflinger, E. (2017). Lowerbackpain in nursesworking in homecare: linked to workfamilyconflict, emotionaldissonance, and appreciation?

Friedman, S. D., \& Greenhaus, J. H. (2000). Work and family-Allies or enemies? What happens when business professionals confront life choices. New York: Oxford University Press.

Greenhaous, J. H., \& Beutell, N. J. (1985). Sources of Conflict between Work and Family Roles. The Academy of Management Review, 10, 76-88.

Gutek, B. A., Searle, S.,\& Klepa, L. (1991). Rational versus gender role explanations for workfamily conflict. Journal of Applied Psychology, 76, 560-568. 
Hagqvist, E. (2017). Work-Family Conflict and Well-Being Across Europe: The Role of Gender Context.

Houlfort, N., Philippe, F. L., Bourdeau, S., \& Leduc, C. (2017) A Comprehensive Understanding of the Relationships Between Passion for Work and Work-Family Conflict and the Consequences for Psychological Distress. International Journal of Stress Management. Advance online publication.

Kahn, R. L., et al. (1964). Organizational stress. New York: Wiley.

Kalous, J. (1983). Průvodce př́pravou empirického výzkumu pro pedagogy a psychology. Praha: PÚ JAK ČSAV.

Kozubík, M., Lehoczká, L., \& Rác, I. (2014). Poradenstvo v sociálnych službách. Nitra : UKF v Nitre.. Lambert, E. G., et al. (2016). The relationship of work-family conflict with jobstress among Indian police officers: a research note.

Li, A., Bagger, J., \& Cropanzano, R. (2016). The impact of stereotypes and supervisor perceptions of employee work-familyconflict on job performan ceratings.

MacDermid, S. M. (2005). (Re)Considering conflict between work and family. In E. E. Kossek \& S. J. Lambert, Work and life integration: organizational, cultural and individual perspectives (pp. 19 39). New Jersey: Lawrence Erlbaum Associates

Mason, C. (2002). 100 Most Frequently Cited Work-Family Articles. Retreived from: <http://wfnetwork.bc.edu/loppr/top100.pdf>

Mauno, S., Ruokolainen, \& M. Does (2017). Organizational Work-Family Support Benefit Temporary and Permanent Employees Equally in a Work-Family Conflict Situation in Relation to Job Satisfaction and Emotional Energy at Work and at Home? Journal of Family Issues.

Odrášková, B., Kozubík, M., \& Odráška, L. (2016). Influence of Family Enviroment on Adolescent Deviant Behavior. In CER Comparative European Research 2016: International Scientific Conference for Ph.D. students of EU countries March 28-31, 2016, London (pp. 154-158). London: Sciemcee Publishing.

O‘ Neill, O. A. (2017). Is Love All You Need? The Effects of Emotional Culture, Suppression, and Work-family Conflict on Firefighter Risk-Taking and Health.

Rác, I., \& Kozubík, M. (2012). Manželstvo - utópia dnešnej doby? In Sociálne posolstvo Jána Pavla II. pre dnešný svet. Ekonomika vs. kultúra ako hybné sily civilizačných zmien (s. 537-541).

Ružomberok: KU.

Rác, I, Kozubík, M, \& Mátel, A. (2016). Násilie páchané na rómskych ženách v partnerských vzt'ahoch Sociální práce/Sociálna práca, (6), 62-77.

Reichl, C, Leiter, M. P, \& Spinath, F. M. (2014). Work-nonworkconflict and burnout: A metaanalysis. Human Relations, 67(8), 979-1005.

Smith, T., Hughes, K., \& DeJoy, D. M. (2017). Assessment of relationships between workstress, workfamilyconflict, burnout and firefightersafety behavior outcomes.

Timms, C, Brough, P, \& Siu, O. L. (2015). Cross-culturalimpact of work-lifebalance on health and workoutcomes. In L. Lu \& C. L. Coooper (Eds.), Handbook of Research on Work-Life Balance in Asia. Cheltenham: Edward Elgar.

Vanková, K, \& Kozubík, M. (2012). Sociálna spravodlivost' - princíp sociálneho života s reflexiou na ochranu práv diet'at'a. Vychovávatel', 5(2), 2-8.

Yi, J., KwongKwan, H., Hu, Y.-L., \& Chen, S. (2017). Revenge Exacerbates the Effects of Interpersonal Problems on Mentors' Emotional Exhaustion and Work-Family Conflict: A SelfDefeating Perspective. Hum Resour Manage, 56, 851-866. doi:10.1002/hrm.21808. 


\title{
Family versus work: transfer, positives, changes
}

\begin{abstract}
The paper discuses a relationship between job responsibilities and family life in the context of an overlap between both areas, positives and changes. The main study objective is to identify problematic areas resulting from work-family conflict. The sample consisted of 130 respondents, including 82 women and 48 men. The research method was a self-designed non-standardized questionnaire. A simple analysis of frequencies, and percentages were used for data analysis. The biggest barrier of the relationship between work and family life is the absence of boundaries between the studied areas. Up to $68 \%$ of the respondents work from home in nonworking time. The positives of practising a profession include experience, knowledge, self-realization and practice. The stated attributes are even preferred to financial evaluation with a lead of $17 \%$. The respondents see the solutions in the reduction of working hours and the introduction of better employee benefits (71\%). Twenty-nine per cent of the respondents do not want any changes. As the biggest problem we perceive insufficient support of employees by employers in the areas of solving problem situations in a workplace as well as an insufficient introduction of benefits and support in programmes for families. In the future, it would be suitable to measure the studied issue in a larger sample and with the use of more sophisticated statistical measurements, which might bring other more valid results.
\end{abstract}

Keywords: family, conflict, work-family conflict, Slovakia, benefits 